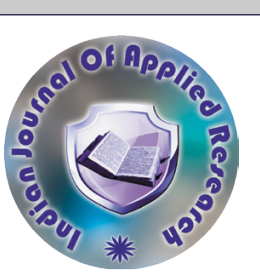

Psychology

A PSYCHOLOGICAL STUDY ON BURNOUT AMONG SCHOOL TEACHERS

\section{Dr. S. Padmasundari}

ABSTRACT) The present study examined the levels of burnout among school teachers. 100 samples (52 Males and 48 Females) were collected randomly. Maslach Burnout Inventory-Educator Survey (MBI) (1996) was used for this study. This test consists of 22 statements self report survey which uses a Likert type 7-point scale for responses. An answer ranges from "never" to "every day". Multiple regression analysis was carried out to determine how much each demographic variable make an impact on three burnout sub-scales; emotional exhaustion, depersonalization, and personl accomplishment. The results revealed that the three dimensions of Maslach's Invetory, and the teacher' biographical characteristics have a very minute relationship and do not make any significant influence in predicting burnout of teachers.

KEYWORDS : Emotional Exhaustion, Personal Accomplishment, Depersonalization.

\section{INTRODUCTION}

Teaching is a very stressful profession and the teachers who work in schools are now facing many challenges with regard to multi-faceted roles to be played within a single hour in the classroom, which they perceive them as exceeding their personal resources and thus resulting stress and burnout. Teachers are facing many challenges with regard to teaching, learning and evaluation for which the emphasis was given to adopt various formative assessment techniques rather than go for with summative evaluation adopted earlier. As a fact that the teachers' role and status are a reflection of the forces which influence the nature of education; the teacher is what educational system demands (Lee, 1966 cited in Ward, 1986). Teachers' role encompasses not only teaching specific content and monitoring students in the love of learning, but functioning as frontline social workers. Many of them find the demand of being an effective teacher in today's school difficult and at times stressful. Previous studies on teacher stress and burnout revealed that the situation like this leads to teacher strain and exhaustion of energy due to current changes in their teaching life (Blasé, 1986). The present study focuses on the onset of burnout among teachers who recently implemented this innovative system.

Maslach and Jackson refined the meaning and measurement of the burnout construct in the 1980s. Maslach and Leiter showed clearly that burnout is debilitating psychological condition brought about by unrelieved work stress, resulting in; depleted energy and emotional exhaustion, lowered resistance to illness, increased depersonalization in interpersonal relationship, increased dissatisfaction and increased absenteeism and word inefficiency. The extent of stress and the burnout experienced by the teachers depends upon how stress is handled by them (Schwab, 1985). Burnout cannot be completed without investigating the relationship between the teacher demographics and burnout so that the present study also included the aspects of these factors and their effect on burnout. According to Schwab et.al.(1986) Teacher burnout refers to a psychological syndrome caused by depersonalization, emotional exhaustion and a diminished sense of personal accomplishment. According to Maslach and Leiter (1997) Teacher burnout is characterized by a condition in which a teacher cannot perform his/her day-to-day duties of teaching due to a sense of tiredness, frustration, exhaustion, and/or hopelessness.

Haberman (2009) also identified that in addition to problems which existed in schools, several demographic characteristics were also related to burnout; teachers' age, level of education, religiousness and years of married have significant mediating effects on burnout. But in contrast to Lens and Jesus findings (1995) he showed that younger less experienced teachers reported feelings of greater alienation, powerlessness and greater stress.

\section{METHODOLOGY:}

\section{SAMPLE:}

One hundred Samples were selected from various schools in Coimbatore. The total groups of the population in terms of age, gender, educational level, marital status was essentially needed to conduct this study, and random sampling technique is used for this study.

\section{TOOLSADMINISTERED}

The present study examined the levels of teacher burnout in the three dimensions of Maslach Burnout Inventory-Educator Survey (1996)(MBI) namely: Emotional Exhaustion(in Which one feels emptied of personal emotional resources and becomes highly vulnerable to stressors), Depersonalization (in which one distances oneself from others and views others impersonally) and Reduced Personal Accomplishment(in which one devalues one's work with others) are considered as the dependent variables of this study. Seven demographic variables which are considered to be played an important role in teacher burnout were selected and these are the independent variables of this study. They are age, gender, marital status, level of education, teaching experiences, student teacher ratio and the total number of working hours per week. This test consists of 22 statements self report survey which uses a Likert type 7-point scale for responses. An answer ranges from "never" to "every day".

\section{RESULTS AND DISCUSSION}

Table no.1 Description of sample in terms of the proportion under each category of teacher demographic

\begin{tabular}{|c|c|c|}
\hline Age group & $\begin{array}{l}25-40 \\
46 \%\end{array}$ & $\begin{array}{l}41 \text { and above } \\
54 \%\end{array}$ \\
\hline $\begin{array}{l}\text { Teaching } \\
\text { experience }\end{array}$ & $\begin{array}{l}\text { Less than } 10 \text { years } \\
54 \%\end{array}$ & $\begin{array}{l}\text { More than } 10 \text { years } \\
46 \%\end{array}$ \\
\hline Client load & $\begin{array}{l}\text { Less than } 33 \\
40 \%\end{array}$ & $\begin{array}{l}\text { More than } 34 \\
60 \%\end{array}$ \\
\hline $\begin{array}{l}\text { Total number of } \\
\text { working hours }\end{array}$ & $\begin{array}{l}\text { Less than } 25 \text { hours } \\
51 \%\end{array}$ & $\begin{array}{l}\text { More than } 26 \text { hours } \\
49 \%\end{array}$ \\
\hline Gender & $\begin{array}{l}\text { Male } \\
52 \%\end{array}$ & $\begin{array}{l}\text { Female } \\
48 \%\end{array}$ \\
\hline Civil Status & $\begin{array}{l}\text { Married } \\
67 \%\end{array}$ & $\begin{array}{l}\text { Unmarried } \\
33 \%\end{array}$ \\
\hline Educational Level & $\begin{array}{l}\text { Holding one degree } \\
59 \%\end{array}$ & $\begin{array}{l}\text { Holding more than one } \\
\text { Degree } \\
41 \%\end{array}$ \\
\hline
\end{tabular}

Table 2.1 The Model summary of regression analysis for Emotional Exhaustion

\begin{tabular}{|l|l|l|l|}
\hline Model & $\mathrm{R}$ & R square & $\begin{array}{l}\text { Adjusted R } \\
\text { square }\end{array}$ \\
\hline 1. Experience & .351 & .124 & .115 \\
\hline $\begin{array}{c}\text { 2. Experience } \\
\text { Client Load }\end{array}$ & .411 & .169 & .152 \\
\hline
\end{tabular}

The results showed that for the first model its value was 0.115 which means that experience accounted for $11.5 \%$ of the variation in $\mathrm{EE}$ (Emotional Exhaustion). In this second model after the inclusion of client load into this model, resulted an increase in value to 0.152 or $15.2 \%$. Therefore, when client load was entered into the model this accounted for an extra $(0.152-0.115) 3.7 \%$ of the variance in EE score. However, the first model was significant at $5 \%$ level $(\mathrm{F} 1,96=9.774, \mathrm{p}<.05)$

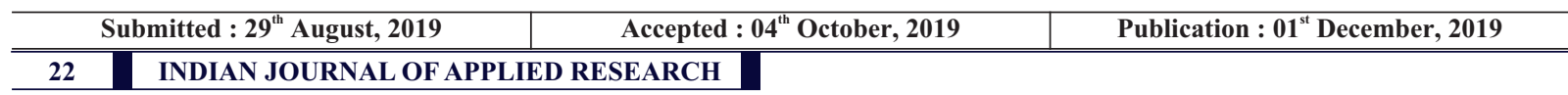


Table 2.2 The Parameters of model-Emotional Exhaustion as an outcome variable

\begin{tabular}{|l|l|l|l|}
\hline Model & Beta & t-value & Sig. \\
\hline 1. Experience & -.351 & -3.70 & .000 \\
\hline 2. Experience & -.342 & -3.68 & .000 \\
Client Load & -.214 & -2.30 & .024 \\
\hline
\end{tabular}

Table 2.2 showed that experience of the teachers and the client load were significantly but negatively related to EE implied that as experience and client load increase the level of EE decreases. Even though, for this model, experience, $\mathrm{t}(100)=-3.68, \mathrm{p}<.05$ and client load $\mathrm{t}(100)=-2.30, \mathrm{p}<.05$ were seemed significant predictors of EE it can be shown that experience had slightly more impact than the client load on EE. Finally other independent variables like age $(\mathrm{t}=.63, \mathrm{p}>.05)$ gender $(\mathrm{t}=.98, \mathrm{p}>.05)$, civil status $(\mathrm{t}=.062, \mathrm{p}>.05)$, educational level $(\mathrm{t}=1.83, \mathrm{p}>.05)$ and working hours $(\mathrm{t}=1.25, \mathrm{p}>.05)$ were not significant predictors in this model in explaining the change in the scores of EE.

Table 3.1 The Model summary of regression analysis for Depersonalization

\begin{tabular}{|l|l|l|l|}
\hline Model & $\mathrm{R}$ & R square & Adjusted R square \\
\hline Client Load & .331 & .109 & .100 \\
\hline Work hours & .437 & .191 & .174 \\
\hline Experience & .484 & .235 & .211 \\
\hline Educational level & .527 & .271 & .240 \\
\hline
\end{tabular}

Table 3.1 indicated that client load accounts for $10 \%$ of the variation in depersonalization subscale. For the first $17.4 \%$, for the third $21.1 \%$ and for the second model this value increases to $24 \%$ of the variance in Depersonalization which implied that the final model accounted for $24 \%$ of the variance in the scores of Depersonalization. However, the overall significance of the second model F2, 94=8.757,p<.05) is confirmed

Table.3.2 The parameters of model- Depersonalization as an outcome variable.

\begin{tabular}{|l|l|l|l|}
\hline Model & Beta & t-value & Significant level \\
\hline 1. Client load & -.331 & -3.45 & .001 \\
\hline 2. Client Load Working & -.367 & -3.97 & .000 \\
hours & .288 & 3.12 & .002 \\
\hline 3. Client Load & -.355 & -3.92 & .000 \\
Working hours & .265 & 2.91 & .005 \\
Experience & -.210 & -2.32 & .002 \\
\hline 4. Client Load & -.339 & -3.80 & .000 \\
Working hours & .233 & 2.57 & .012 \\
Experience & -.258 & -2.83 & .006 \\
Educational & .199 & 2.18 & .032 \\
Level & & & \\
\hline
\end{tabular}

Table 3.2 shows the Client Load $(b=-.339, \mathrm{p}<.05)$ and Experience $(b=$ $.258, \mathrm{p}<.05)$ were significantly but negatively related to depersonalization dimension which indicated that as long as the class was filled with students, and as the teachers having more experience in teaching they seemed less likely to depersonalize with students. More experience teachers less likely treating their students as if they were impersonal objects. Working hours $(\mathrm{b}=.233, \mathrm{p}<.05)$ and Educational level $(b=.199, p<.05)$ of teachers showed positive and significant relationship with depersonalization which implied that with increasing the total number of working hours per week and level of education, the teachers more likely to experience depersonalization. Hence, of the four teacher demographics, client load was the significant predictor $(\mathrm{t}$ $(100)=-3.8, \mathrm{p}<.05)$ of depersonalization followed by teaching experience $(\mathrm{t}(100)=-2.83, \mathrm{p}<.05)$, working hours $(\mathrm{t}(100)=2.57, \mathrm{p}<.05)$ and educational level $(\mathrm{t}(100)=2.18, \mathrm{p}<.05)$. In sum age $(\mathrm{t}(100)=-$ $.98, \mathrm{p}>.05)$, gender $(\mathrm{t}(100)=.84, \mathrm{p}>.05)$ and civil status $(\mathrm{t}(100)=1.7, \mathrm{p}>.05)$ of the teachers were seemed to be poor predictors of depersonalization.

Table 4.1 The model summary of regression analysis for Personal Accomplishment

\begin{tabular}{|l|l|l|l|}
\hline Model & R & R square & Adjusted R square \\
\hline Experience & .378 & .143 & .134 \\
\hline Working hours & .492 & .242 & .226 \\
\hline Client Load & .573 & .327 & .306 \\
\hline
\end{tabular}

Table 4.1 showing the result of Personal Accomplishment (PA) dimension, in the first model only experience was entered as a predictor. For the second and final with experience, working hours and client load were entered as predictors of depersonalization, other predictor like age, gender, civil status and educational level were not entered into this model as they seemed to be poor predictors of the PA. The adjusted $\mathrm{R}$ square for the final model was .306 indicated that $30.6 \%$ of the variance was accounted by these predictors on PA scores. Since F3, 95 $=15.384, p<.05$ as far as the effect of independent variables on PA scores was concerned, the model seemed significant.

Table 4.2 The parameters of model -Personal Accomplishment as an outcome variable.

\begin{tabular}{|l|l|l|l|}
\hline Model & Beta & t-value & Significant level \\
\hline 1. Experience & -.378 & -4.02 & .000 \\
\hline 2. ExperienceWorking hours & -.344 & -3.85 & .000 \\
& .316 & 3.54 & .001 \\
\hline 3. Experience Working hours & -.327 & -3.86 & .000 \\
Client Load & .355 & 4.16 & .000 \\
& -.295 & -3.47 & .001 \\
\hline
\end{tabular}

The standardized beta coefficients, $\mathrm{t}$ values and the probability for these measures for the scores of PA are given in Table 4.2. The contribution of working hours as a predictor was high $(b=355, t=4.16, p<.05)$ when compared with experience $(b=-.37, t=$ $3.861, \mathrm{p}<.05)$, and client load $(\mathrm{b}=-.295, \mathrm{t}=-3.472, \mathrm{p}<.05)$ to the PA scores indicated that experience had a greater impact on PA scores than the later. If age $(\mathrm{t}=1.51 . \mathrm{p}>.05)$, gender $(\mathrm{t}=.429, \mathrm{p}>.05)$, civil status $(\mathrm{t}=.563, \mathrm{p}>.05)$ and educational level $(\mathrm{t}=.408, \mathrm{p}>.05)$ are entered in to the model they would not have a significant impact on the model's ability to predict PA.

\section{CONCLUSION}

The group differences of teacher demographics are significantly related to the levels of burnout, the attention should be paid in this regard in order to alleviate the problem at the onset. Some teachers overestimate their stressors and strains and should be more realistic when comparing themselves with other School Teachers. They probably underestimate the impact they still have on the learning process and the personal development of the children in their class. The private school system with the possible elements that aggravate the onset of teacher burnout, the issue of teacher burnout has been of increasing concern to educators because of its association with high rates of teacher turnover, poor job performance and huge costs to the system. Teachers' psychological wellbeing is related to their ability to deal with student behaviour. More qualified teachers have high turnover rates.

\section{IMPLICATIONS}

The implication of the study is not on the nature and characteristics of the teacher, rather they were trying continuously to providing adequate training to the teachers in order for improving quality of education and thus personal characteristics of teachers were not handled adequately.

\section{RECOMMENDATION:}

The size of the sample taken for this study was only one hundred which is not be able to represent the vast number of teachers. Similar study can be undertaken with large number of samples in different setting to strengthen the research.

\section{REFERENCES:}

1. Blasé,J. (1986). A qualitative analysis of sources of teacher stress: Consequences for performance. American Educational Research Journal. Vol.23 (1).pp13-40. Retrieve February 27, 2011 from: http;//www,blasé.myweb.uga.edu/home/publications.html

2. Haberman, M. (2009) Teacher Burnout in Black and White. The Haberman Educational Foundation. Retrieved 24th February, 2011 from: http://www. ednews. org/ articls/ teacher- burnout- in-black-and-white-html

3. Lens, W., and Jesus, S.N.D. (1999) Understanding and preventing teacher burnout. A source book of International Research and Practice

4. Maslach. C and Leiter, M.P. (1997). The truth about Burnout: How organizations cause personal stress and what to do about it. San Francisco, California: Jossey-Bass.

Schwab, R. L., Jackson. S.E., Schuler, R.S. (1986) Educator Burnout; Sources and consequences. Educational Research Quarterly. Vol. 10(3): pp 30-40.

consequences. Educational Research Quarterly. Vol. T0(3): pp 30-40.
Schwab, R.I.(1985)Teacher Stress and Burnout. The International Encyclopedia of Education. Vol. 10, pp.6059-6062). New york: Pergamon Press.

7. Lawrence H.S.S (2004). Hand Book of Implementation of Higher Secondary Education in Tamil Nadu

8. Ward, T.W.O. Improvement of Educational Practice. Encyclopedia of Educational Research. 4th ed. (vol.10,pp. 6059-6062). New York: Pergamon Press. 